
ОРИГИНАЛЬНЫЕ СТАТЬИ

\title{
HOME RANGE, MOBILITY AND HIBERNATION OF BROWN BEARS (URSUS ARCTOS, URSIDAE) IN AREAS WITH SUPPLEMENTARY FEEDING
}

\author{
Vladimir R. Todorov ${ }^{1,2}$, Diana P. Zlatanova ${ }^{3}$, Kalina V. Valchinkova ${ }^{1}$ \\ ${ }^{1}$ Institute of Biodiversity and Ecosystem Research, Bulgarian Academy of Sciences, Bulgaria \\ e-mail:vladimirtodorov.r@gmail.com,kvalchinkova@gmail.com \\ ${ }^{2}$ Balkani Wildlife Society, Bulgaria \\ ${ }^{3}$ Sofia University «St. Kliment Ohridski», Bulgaria \\ e-mail:dianazlatanova@biofac.uni-sofia.bg
}

Received: 03.04.2020. Revised: 05.08.2020. Accepted: 14.08.2020.

\begin{abstract}
Supplementary feeding, although a common practice, is seldom studied in terms of its effect on non-targeted species, such as the brown bear (Ursus arctos). We conducted a GPS-GSM telemetry study on nine individuals (out of about 100 supposedly inhabiting that area) with the aim to inspect how supplementary feeding stations affect home range size, mobility and hibernation. We formulated three hypothesis: 1) there is a correlation between the home range size and the density of feeding stations; 2 ) the influence of the artificial feeding stations is not changing during hyperphagia and outside the hyperphagia; 3 ) hibernation is affected by the density of feeding stations, regardless of the areas with trees in masting age present in the home range and forest age heterogeneity. Our analyses showed that the total home range averaged at $148.9 \mathrm{~km}^{2}$ (range: $24.6-605.1 \mathrm{~km}^{2}$ ) with $190.1 \mathrm{~km}^{2}$ for males and $76.9 \mathrm{~km}^{2}$ for females. Five out of nine brown bears never visited feeding stations and the density of feeding stations did not explain the home range size variability, thus not receiving evidence to support our first hypothesis. No evidence was found to reject the second hypothesis, while the third hypothesis was rejected for now with the proviso that our sample is not big enough for robust conclusions. The comparison of the home range size, as well as the average displacement distance during and outside the hyperphagia season showed no significant difference, contrary to the outcome of other published studies. Despite the variability of the masting areas proportions and age class heterogeneity, the lack of significant difference between the core area and the total home range for these two factors implied that these resources were not concentrated in the core area of the species, but were rather uniformly distributed throughout the whole territory. Neither density of feeding stations nor masting area proportions were found to be solely responsible for the formation of the hyperphagia home range. Additionally, the similarity in the sizes of the home range size during and outside the hyperphagia season suggested a balance between the variables forming the home range during these periods. Most of the brown bears in our study hibernate in their core area, predominantly in its very centre $(0.1$ percentile), as earlier hibernation than reported for this region from other studies was recorded. Further studies with a larger sample size on the role of the forest age heterogeneity and mast production on the formation of the home range are needed.
\end{abstract}

Key words: artificial feeding station, forest age heterogeneity, GPS-telemetry, hyperphagia, mast production

\section{Introduction}

The brown bear (Ursus arctos Linnaeus, 1758) is a species of the highest importance for ecosystems all over Europe. Due to its biology of a carnivore, it faces a lot of problems sharing the European landscapes with humans (Chapron et al., 2014). Human activities like forestry, game hunting, livestock farming and even tourism are having an impact on the brown bear distribution and behaviour. One of the human activities with a significant impact on the bears is the supplementary feeding (LCIE, 2018). Worldwide, this practice is widely used for herbivores (Linnell et al., 2020), even in national parks (van Beeck Calkoen et al.,
2020), where management interventions should be kept to a minimum. In Bulgaria, the intentional artificial feeding, targeting bears was banned with the National Action Plan (MOEW, 2008). This step proved not to be effective as the bears continued using the numerous ungulate feeding stations, in both state and private hunting grounds.

Three of the most studied topics in the brown bear-related spatial research are home range size, mobility and habitat use, with numerous publications worldwide (e.g., Seaman \& Powell, 1990; McLoughlin et al., 2000; Dahle \& Swenson, 2003; Ćirović et al., 2015; Gavrilov et al., 2015; Seryodkin et al., 2017). Yet, according to our knowledge, 
none of them were trying to relate the home range size to the effect of artificial feeding. Such a study was done on the red deer (Jerina, 2012).

Few publications deal with artificial feeding effect on bear movement (Selva et al., 2017), winter activity (Bojarska et al., 2019), diet (Kavčič et al., 2015), habituation/boldness to humans (Kojola \& Heikkinen, 2012; Steyaert et al., 2016) and livestock depredation (Kavčič et al., 2013). The supplementary feeding is known to affect the territorial and social behaviour, mobility and activity of bears (Jerina et al., 2012; Selva et al., 2017), without proof that it is solving human dimension problems such as livestock depredation (Kavčič et al., 2013). Moreover, the provision of additional food might have some unforeseen negative effects on non-target species (Selva et al., 2014; Fležar et al., 2019).

The relationship between the home range size and the mast production is also poorly studied. So far, it was found that the mast production affected the home range use (Kozakai et al., 2011), movement behaviour (Koike et al., 2012) and daily activity time budgets (Kozakai et al., 2013) of the Japanese black bear (Ursus thibetanus Cuvier, 1823). This effect was also noted for specific changes in the Scandinavian brown bear behaviour, such as seasonal activity patterns, human settlement visits and habitat use (Hertel et al., 2019). For the black bear, some attempts were made to predict whether hard mast production would be related to bear visitation of baiting stations (Clark et al., 2005).

For the analysis in this study, we used the effects of two main variables - supplementary feeding stations presence and areas with acorn producing tree species to set up the following hypotheses:

1) There is a correlation between the home range size and density of the feeding stations, regardless of the habitat quality. Thus, the density of feeding stations plays an important role in shaping the home range.

2) The influence of the artificial feeding stations is not changing during hyperphagia and outside the hyperphagia, regardless of the habitat quality in sense of mast area distribution and size and forest age heterogeneity.

3) Hibernation, defined as start and duration, is affected by the density of feeding stations, regardless of distribution of areas with trees in masting age. This hypothesis was based on the biological assumption that after the natural food sources depletion, the bears usually go into hibernation. The presence of more artificial feeding stations will lead to a change in the natural hibernation cycle (earlier or later hibernation from the «typical» recorded for the country, or even no hibernation at all).

\section{Material and Methods}

\section{Study area}

The study was conducted in the central part of the Stara Planina Mnt., on the grounds of the Central Balkan National Park and several State Forestry and State Hunting Enterprises (Fig. 1). The State Hunting Enterprises are units not only for the management of forests and timber production like the Forestry Enterprises, but also include additional activities for intensive game management that include intensive supplementary feeding.

This study area was chosen as it is a part of the Central Balkan segment of the East Balkan population (Linnell et al., 2008; Kaczensky et al., 2013) with the highest registered density of the species in the country (1-2 bears $\left./ 10 \mathrm{~km}^{2}\right)$ (MOEW, 2008). The estimated number of the population in the Central Balkan segment was reported to be around 100 bears, so we consider our sample representative for this relatively isolated part of the population.

The Central Balkan National Park is covering a larger part of our study area $\left(716.7 \mathrm{~km}^{2}\right)$, with the highest altitude of $2376 \mathrm{~m}$ a.s.1 (peak Botev). It was created to protect the largest non-urbanised and compact common beech (Fagus sylvatica L.) forest complex in the country, with an average age of the trees $\sim 130$ years. The rest of the forest complexes include the xero-thermophilic oak (Quercus sp.) woods, hornbeam (Carpinus sp.) and scattered patches of coniferous formations. More than $60 \%$ of the study area is covered predominantly with Fagus sylvatica. The rest are meadows, pastures, and agricultural land. The area is scarcely populated with humans, (density: 58.7 people $/ \mathrm{km}^{2}$, range: $14.0-117.5$ ).

In the study area, 106 supplementary feeding stations for ungulates (Cervus elaphus Linnaeus, 1758, Sus scrofa Linnaeus, 1758 and Capreolus capreolus Linnaeus, 1758), were registered (Fig. $1)$. These stations are located mainly in the hunting grounds of the State Hunting and Forestry Enterprises (Electronic Supplement 1). The feeding stations placement is based on the Regulation of Hunting and Game Conservation act (MAFF, 2001), according to which for Cervus elaphus and Capreolus capreolus there should be one feeding station per 10 individuals and additionally one feeding station per $3 \mathrm{~km}^{2}$ hunting ground for Sus 
scrofa. Only 28 of the 106 feeding stations are situated in the Central Balkan National Park providing food mostly in the winter or on irregular intervals during the other seasons. The food provided on all the feeding stations is mainly corn (Zea mays L.). Brown bears are attracted by this food of high nutritional value, as Gunchev (1989) has confirmed a high percentage of corn intake by the species in the study area. Additionally, in the study area, brown bears were frequently registered by camera traps at supplemental feeding stations. On the hunting grounds, the food is provided more intensively, once per every 1-2 days in winter and spring and at least once per week in the other seasons (Electronic Supplement 2). During our study, $73.6 \%$ of these feeding stations were providing food regularly and $26.4 \%$ seasonally. Because of the variability of feeding stations management (differences in the frequency of feeding was found even within the same stations) for the purpose of this study, we assumed that all the feeding stations were attractants for the brown bears per se. Most of the stations had automatic feeders (not attractive for brown bears, because of the small amount of food provided periodically). However, almost all of these stations were supplemented with an additional amount of food, provided manually in various quantities, thus increasing their attractiveness to the animals. All of the feeding stations were visited for food or simply checked by brown bears, regardless of the intensity and type of feeding. None of the stations were providing enough food to sate one individual brown bear, especially with the competition of Sus scrofa and Capreolus capreolus.

\section{Capture and handling of brown bears}

As the brown bear is a strictly protected species in Bulgaria, it is under the regulation of Bulgarian Biodiversity Law, Annex 3. As such, the capture and handling of the brown bears were conducted with a permit from the Ministry of Agriculture, Food and Forestry, in which the handling procedure was prescribed and strictly followed. The capture sites and capture time were chosen based on the brown bears' presence, according to information from the Central Balkan National Park and SFE/SHE staff and camera trap data, which recorded the frequency of brown bear visits to the places later assigned as capture sites.

For the capture, we used standard Aldrich snares (Aldrich Snare Co., Washington). The trap placement followed the general procedures for using Aldrich snares (Jonkel, 1993). We used a brown bear capture alert system during the night, to minimise the brown bear stay in the trap to less than two hours.

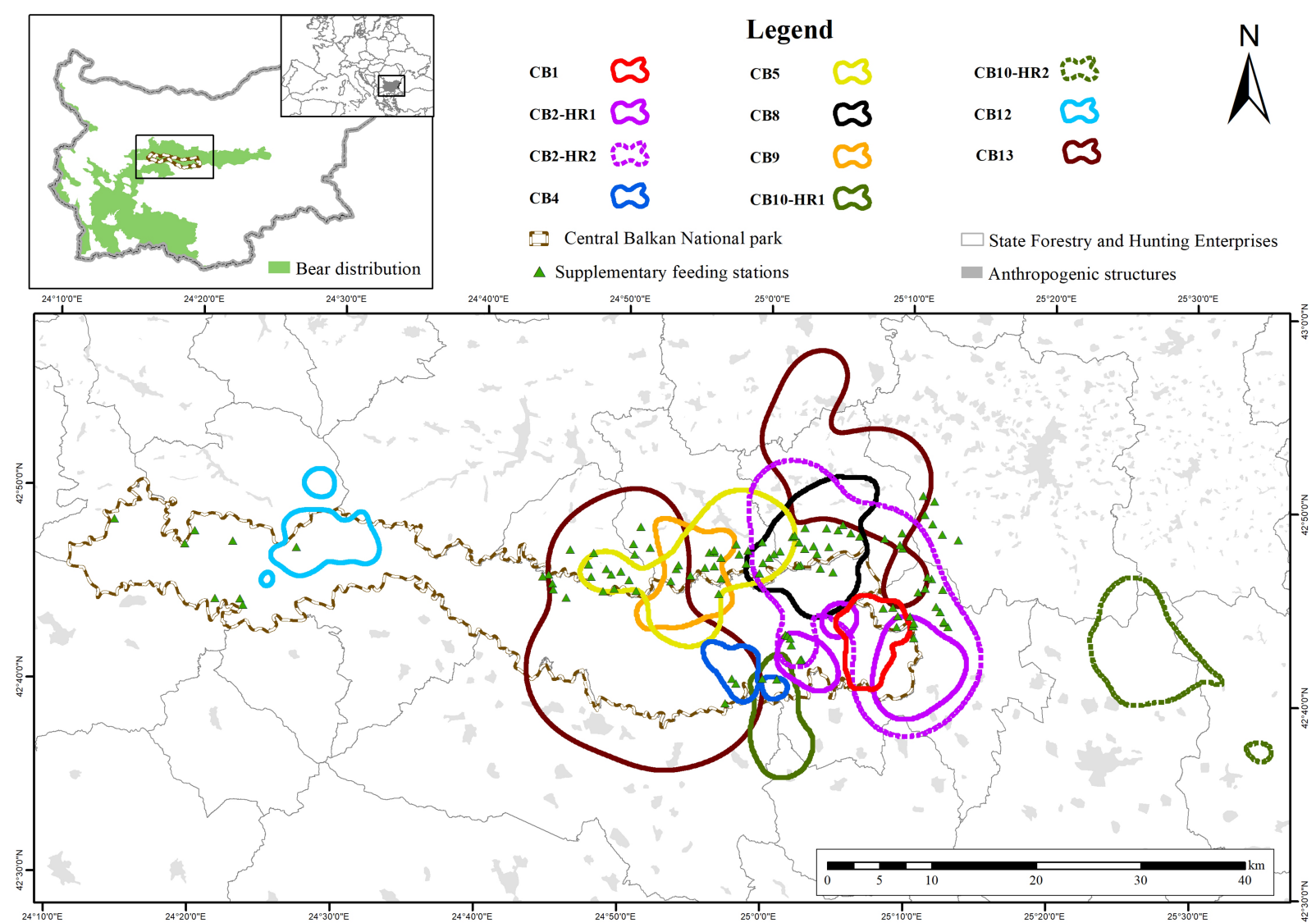

Fig. 1. Map of the study area and total home ranges of the GPS-collared individuals as calculated by the $90^{\text {th }}(0.9)$ percentile. 
During the study period (2007-2019) we captured 15 brown bears, nine of which were used in the current analysis (Table 1). Two of the collared animals (CB5 and CB9) were second-year cubs, led by their mothers (present at the capture site) until finishing the study. This is why we consider both in the group of females since they represented their mother's territory. One of the brown bears was captured twice (CB2, Table 1). After the second capture, it was released in about $12 \mathrm{~km}$ straight line distance from the capture site. Another brown bear CB10 (also released from a poacher's snare) was released about $5 \mathrm{~km}$ straight line distance from the capture site within the boundary of the Central Balkan National Park. Most brown bears were captured in autumn when brown bears are in the hyperphagia period $(n=7)$. The capture site locations were recorded with a GPS device.

Upon capture, the animals were tranquilised remotely, weighed and measured. The status of the teeth was recorded for approximate assessment of the age.

Two different types of GPS-collars were used in this study: Vectronic (Vectronic GPS Pro Lite, Vectronic Aerospace GmbH, Germany) and Followit (Tellus GPS Medium Plus, Followit, Lindesberg AB, Sweden), equipped with a GSM module for data transfer.

\section{Data collection and spatial analyses}

In the current study, we used an individualbased approach to GPS telemetry data from the captured individuals to analyse the home range size, mobility and hibernation according to predefined variables.

\section{GPS-collars data}

The collars were initially set to record locations at a varying time interval, ranging from $2 \mathrm{~h}$ to $12 \mathrm{~h}$, depending on the season: every $2 \mathrm{~h}$ during spring, summer and autumn and every $12 \mathrm{~h}$ during winter (power save mode). During the breeding season, some of the collars were set to take more frequent fixes (10 min. per fix for one week). This called upon the need for sub-sampling to equal time frame, due to two reasons: 1). dealing with autocorrelation (De Solla et al., 1999), which is a pre-requisite for the kernel density estimation model, chosen for home range estimation in our study; 2) analysing and comparing the step length (Euclidean distance between subsequent locations, forming the animal displacement in space, hereafter called «displacement») across individuals throughout the whole study period. Twelve hours between each location fix (at 00:00 and 13:00) were chosen (Table 1) to compromise between the shortest step length possible, the coincidence of available GPS fixes from the collars, the continuousness of the data flow and the possible effect of correlated locations. Despite that in most of the published literature the daily $(24 \mathrm{~h})$ displacement distances were considered, many recent studies showed that the brown bear activity (including the alternation of the species rest and activity) did not support the idea of discrete 24-h samples (including for displacement) as biologically meaningful. Many behavioural studies recommend using data at a high as possible resolution. That is why in our study we used the highest possible resolution (12 h.). The same was used for building the utilisation (kernel) model of the home range.

Table 1. Details for the captured and collared brown bears (Ursus arctos) used in this study: ID, sex, age at capture (estimated by the teeth status), tracking period, the number of GPS fixes collected, numbers of GPS fixes re-sampled at 12-h period and type of capture location. The ID of the individuals follows the capture order

\begin{tabular}{|c|c|c|c|c|c|c|c|c|}
\hline \multirow{2}{*}{ Bear ID } & \multirow{2}{*}{$\begin{array}{l}\text { Bear } \\
\text { name }\end{array}$} & \multirow{2}{*}{ Sex } & \multirow{2}{*}{$\begin{array}{c}\text { Age of } \\
\text { capture, years }\end{array}$} & \multicolumn{2}{|l|}{ Tracking } & \multirow{2}{*}{$\begin{array}{l}\text { Total number } \\
\text { of fixes }\end{array}$} & \multirow{2}{*}{$\begin{array}{c}\text { Number of re- } \\
\text { sampled fixes }(12 \mathrm{~h})\end{array}$} & \multirow{2}{*}{$\begin{array}{c}\text { Type of capture } \\
\text { location }\end{array}$} \\
\hline & & & & Period & Days & & & \\
\hline CB1 & Chara & female & $\sim 3$ & $22.09 .2007-29.07 .2008$ & 310 & 3194 & 407 & feeding station \\
\hline CB2-s1 & Rusi & male & $\sim 2.5$ & 03.11.2009-29.09.2010 & 330 & 1788 & 362 & on animal trail \\
\hline CB2-s2*,*** & Rusi & male & $\sim 3.5$ & $29.09 .2010-20.11 .2010$ & 52 & 742 & 104 & poacher's snare \\
\hline CB4 & Mitko & male & $\sim 4-5$ & $25.11 .2014-16.06 .2015$ & 203 & 616 & 157 & on animal trail \\
\hline CB5 & Ivanka & female cub, with its mother & $\sim 1.5$ & 08.06.2016-29.04.2017 & 325 & 3199 & 357 & feeding station \\
\hline CB8 & Andrey & male & $\sim 5$ & $30.10 .2016-02.08 .2018$ & 641 & 2712 & 806 & feeding station \\
\hline CB9** & Plamen & male cub with its mother & $\sim 2$ & 02.11.2016-01.09.2017 & 303 & 1131 & 375 & feeding station \\
\hline $\mathrm{CB} 10 * * *$ & Jimmy & male & $\sim 2$ & 08.06.2017-20.05.2018 & 346 & 3345 & 623 & poacher's snare \\
\hline CB12 & Boriana & female & $\sim 4-5$ & $07.03 .2018-11.09 .2019$ & 553 & 3506 & 628 & on animal trail \\
\hline CB13 & Spiridon & male & $\sim 6-7$ & $12.12 .2017-08.10 .2019$ & 665 & 5796 & 835 & feeding station \\
\hline
\end{tabular}

Note: $*^{*}$-re-capture (poacher's snare) ${ }^{* *}-$ the cub considered in the female's group, due to representing its mother's area; *** - released at a different from the capture location. 


\section{Spatial analyses}

The supplementary feeding station locations were mapped with a GPS device at the centroid of the feeding ground (with an average area of approximately $30 \times 30 \mathrm{~m})$. Since the acorns are the main part of brown bear's diet during hyperphagia in Bulgaria (Gunchev, 1989), the spatial analysis was focused also on hard mast producing species. As data on the mast production rates is deficient, the current study relied on modelling the forest dynamic using the age and origin of the trees to provide an open concept of the possible mast production. This method allowed us to have a general understanding and the closest to accurate information on possible mast production to use further in the analysis. The spatial distribution of areas with mast (nuts and acorns) capacity was extracted from the Database of Forest Inventory plans, provided by the Executive Forestry Agency/Ministry of Agriculture, Food and Forests. Three main variables (tree species, their age and their origin (from seeds or shoots)), were used to create an algorithm for trees in masting or potentially masting age class based on Delkov (1984). The following tree species, represented within the GPS-collared brown bears' home ranges, were considered: Fagus sylvatica and various oak (Quercus robur L., $Q$. frainetto Ten., Q. petraea Liebl., and $Q$. cerris L.) species. The extracted data were classified into two categories: masting/potentially masting areas and non-masting areas, as in the analyses we used only the proportions of masting/ potentially masting areas in \% (also referred hereafter as masting area). The forest composition is important not only as a food source, but also for providing visibility cover and day resting places for the brown bears. Young forests (age classes from ${ }^{\text {st }}$ to III $^{\text {rd }}$ ) are preferred for those activities due to the higher density of trees, typical for forests in that age. Old forests might be used for avoidance of tourists, since territories with such high age class $\left(\mathrm{VI}^{\text {th }}\right)$ are usually found mainly in Protected Areas. To account for those brown bear activities, we extracted and analysed the forest age heterogeneity, expressed as proportions of forest age classes: 0-20 $\left(\mathrm{I}^{\mathrm{st}}\right), 20-40\left(\mathrm{II}^{\mathrm{nd}}\right), 40-60\left(\mathrm{III}^{\mathrm{rd}}\right)$, $60-80\left(\mathrm{IV}^{\text {th }}\right), 80-100\left(\mathrm{~V}^{\text {th }}\right)$ and over $100\left(\mathrm{VI}^{\mathrm{th}}\right)$ (Hundeshagen, 1826). The non-forested areas are marked as Class 0. During the analyses, it has been taken into consideration, whether the trees are part of a coppice (low) or a high forest, thus adjusting the classification accordingly.

All spatial analyses were conducted with ArcGis Desktop 10.2.2 - ArcMap (ESRI). The resampling of the locations to 12-h intervals, the calculation of the home range and the individual displacement (step length) for each individual were done with ArcMET 10.2.2.v3 extension for ArcGIS Desktop (Wall, 2014).

The annual home ranges for each brown bear were calculated through fixed kernel density distributions (Worton, 1989) and «href» smoothing parameter. Kernel isopleths (i.e. probability contours) were calculated for each $10 \%$ increase in kernel density (hereafter called «percentiles» in decimal values). Percentiles were used for identification of denning site related to the home range. The $50 \%$ and $90 \%$ kernel isopleth range were further defined as a core area (defined as a portion of the total home range which had the most intensive (Samuel et al., 1985) or concentrated (Seaman \& Powell, 1990) use and expressed as $50 \%$ kernel isopleth range, e.g. percentile 0.5$)$ and a total home range area $(90 \%$ kernel isopleth range, e.g. percentile 0.9). The locations outside the $90 \%$ kernel isopleth range were not considered to account for the numerous outliers. For the core and total areas, a comparison of the variables was made between home range size, density (and where appropriate, number) of feeding stations, average 12-h displacement distances (hereafter average displacement distances), proportion of the masting areas (in $\%$ ) and forest age heterogeneity.

To account for the pre-denning conditions (e.g. food resources available), we calculated the home range size during hyperphagia (using fixed kernel density distributions on locations between $1^{\text {st }}$ September and $30^{\text {th }}$ November). The same was done for the period outside this season at 0.9 percentile to be able to test for differences in the home range size and variables during these two periods. The same hyperphagia period is used in the research of Pop et al. (2018) in Romania and by Štofik et al. (2013) in Slovakia, where the climate and respectively vegetation and tree species are similar. For both of these home ranges, we extracted the density of feeding stations, average displacement, and proportions of masting area and tested for differences between the hyperphagia and outside hyperphagia.

We extracted the start-end date of the hibernation and duration in days from the first, inter- 
mediate and, respectively, last location clustered within less than $100 \mathrm{~m}$ (expected GPS error under denning conditions) in the period when denning was expected (end of November - end of March). The denning sites were overlaid with the percentiles layers, identifying their locations within the home range percentiles. Additionally, the proportion of the masting areas and density of feeding stations during hyperphagia were compared to the hibernation data.

\section{Statistical analyses}

All statistical analyses and plots were carried out with Statgraphics Centurion 18.1.11 (Statgraphics Technologies, Inc.). Due to deviation from normality, the non-parametric Mann-Whitney (Wilcoxon), W-test was used to test for differences in medians of the masting areas between the core area and total home range; between the home range sizes in hyperphagia and outside this season; between the displacement distance in the core area and total home range. The same was used for comparison of forest age heterogeneity proportions between core area and total home range. Spearman and Pearson correlations were used to test for relationships between several variables such as home range sizes, density of feeding stations, average displacement, and masting area size. The differences and correlations were tested with two-tailed probabilities at 0.05 significance, within the $95.0 \%$ confidence level.

\section{Results}

\section{Home range size and density of feeding stations}

The shape and size of the individual home ranges (both in sense of core and total area) varied depending on the sex and age of the animals (Fig. 1, Table 2). The average size of the core areas was $37.0 \mathrm{~km}^{2}$ (with the range being 6.5-124.2 $\mathrm{km}^{2}$ ), differed between sexes as follows: 47.23 $\mathrm{km}^{2}$ (median: $23.2 \mathrm{~km}^{2}$ ) for males and $18.9 \mathrm{~km}^{2}$ (median: $16.6 \mathrm{~km}^{2}$ ) for females. The total home range averaged at $148.9 \mathrm{~km}^{2}$ (range: $24.6-605.1$ $\mathrm{km}^{2}$ ) with $190.1 \mathrm{~km}^{2}$ for males and $76.9 \mathrm{~km}^{2}$ for females. The CB2 individual showed a larger home range after the recapture and translocation, despite it being tracked fewer days (330 days before recapture vs. 52 days after recapture). The movement of the subadult CB10 showed a clear dispersal pattern. This individual was tracked for 91 days within its first home range (CB10-HR1 in Table 2). After 11 days of oriented movement, it settled into its new home range (CB10-HR2 in
Table 2), where it was tracked for another 244 days. The second home range had a 1.7 times larger core area, forming a 1.9 times larger total home range than the estimated size of the first home range.

All the home ranges of the studied individuals (with the exeption of the second home range of $\mathrm{CB} 10$ ) contained feeding stations. Yet, five out of nine brown bears (CB1, CB4, CB9, CB10 and CB12) never visited a feeding station during the study period. The core areas of six individuals (Table 2) were associated with a low density of feeding stations (one feeding station per $10 \mathrm{~km}^{2}$ ), in three individuals (CB2-HR1, CB10 - both home ranges and CB12) none were observed. No correlation was found between the core area size and the density of feeding stations (Spearman correlation, $\mathrm{P}=0.480$ ). A clearly positive correlation was found between the number of feeding stations and the total home range size (Spearman's correlation $\rho=0.74$, $\mathrm{df}=10, \mathrm{P}=0.020$ ). However, no correlation was found between the total home range size and the feeding stations density (Spearman correlation, $\mathrm{P}=0.328$ ).

\section{Home range, masting areas and forest age heterogeneity}

The quality of the habitat in the sense of masting area size showed a wider range in the core area (Fig. 2A) than in the total home range. No statistically significant difference was found in the proportions of masting areas between the core area and total home range (Mann-Whitney test on medians, $\mathrm{W}=62.0, \mathrm{P}=0.948$ ). Around half or less of the core areas and total home ranges of most of the studied individuals was covered by a masting or potentially masting trees (Fig. 2B). For two individuals (CB5 and CB8), the core area has shown a concentration (higher density) of feeding stations in the core area, compared to the total home range.

The forest age class proportions for both core area and total home range are presented in Fig. 3A,B. The proportions of non-forested areas (Class 0 ) in the core area were more variable with a larger interquartile range compared to the total home range. The same is valid for the classes III (40-60 years) and V (80-100 years). There is no statistically significant difference between the median values of the age class proportions between the core area and total home range (Mann-Whitney test on medians, $\mathrm{W}=25.5, \mathrm{P}=0.949$ ). 
Table 2. Core and total home range size of the GPS-collared individuals and the density of feeding stations in each core and total home range area

\begin{tabular}{|l|c|c|c|c|}
\hline \multicolumn{1}{|c|}{ Bear ID } & Core area size, $\mathrm{km}^{2}$ & $\begin{array}{c}\text { Density of feeding stations } \\
\text { in the core area per } 1 \mathrm{~km}^{2}\end{array}$ & Total home range* size, $\mathrm{km}^{2}$ & $\begin{array}{c}\text { Density of feeding stations } \\
\text { in the total home range per } 1 \mathrm{~km}^{2}\end{array}$ \\
\hline CB1 & 13.3 & 0.08 & 42.6 & 0.09 \\
\hline CB2-HR1 & 21.4 & 0.00 & 96.8 & 0.10 \\
\hline CB2-HR2 & 109.4 & 0.11 & 349.9 & 0.15 \\
\hline CB4 & 6.5 & 0.15 & 24.6 & 0.12 \\
\hline CB5 & 29.1 & 0.31 & 144.9 & 0.22 \\
\hline CB8 & 32.9 & 0.33 & 109.0 & 0.21 \\
\hline CB9 & 19.4 & 0.10 & 66.3 & 0.18 \\
\hline CB10-HR1 & 13.5 & 0.00 & 50.6 & 0.04 \\
\hline CB10-HR2 & 23.2 & 0.00 & 94.8 & 0.00 \\
\hline CB12 & 13.8 & 0.00 & 53.7 & 0.02 \\
\hline CB13 & 124.1 & 0.04 & 605.1 & 0.05 \\
\hline
\end{tabular}

Note: ${ }^{*}$ - defined as percentile 0.9 .
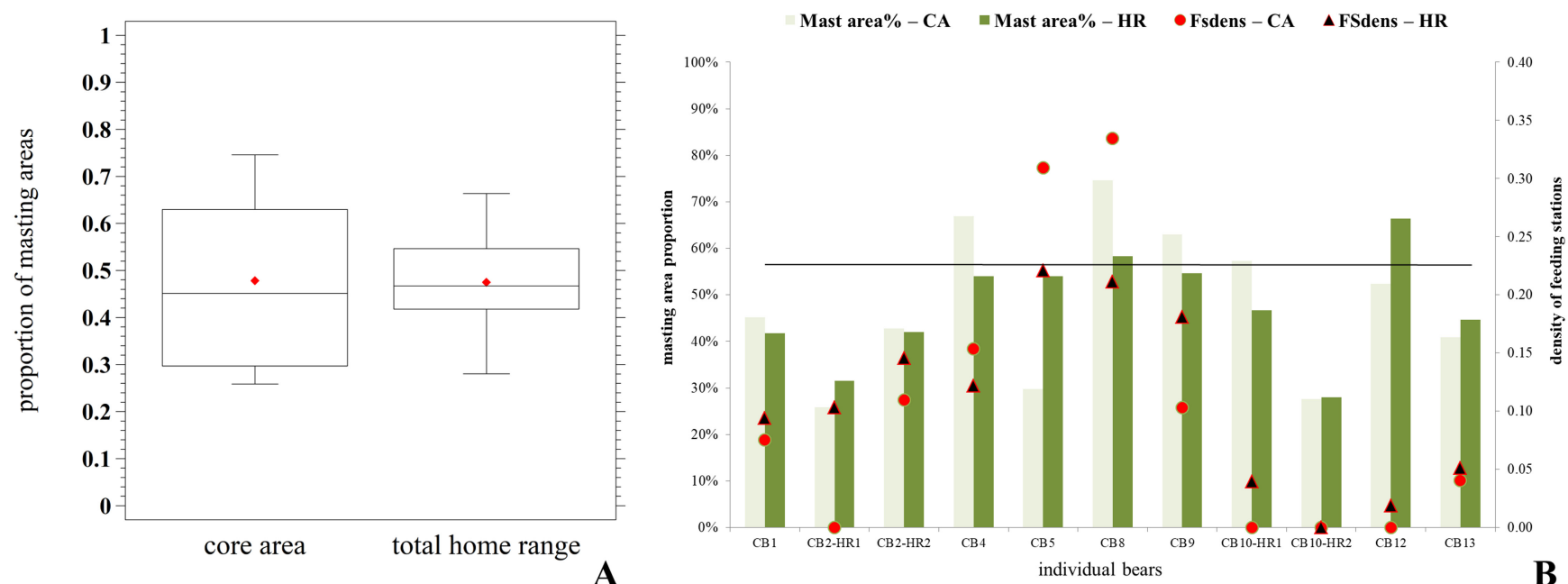

Fig. 2. Proportions of the masting / non-masting areas (\%) within the home range expressed as a decimal index. Designations: A - masting area size for all brown bears in the core and total home range area. (diamond - average value, horizontal line - median value, box - interquartile range); B - comparison of the masting area proportions and density of feeding stations in the core and total home range area per individual. (mast area $\%-\mathrm{CA}$ - proportions of the core area (in \%) covered with masting trees; mast area $\%$ - HR - proportions of the core area (in \%) covered with masting trees; FSdens - CA (red dots) density of feeding stations in the core area; FSdens - HR (black triangles) - density of feeding stations in total home range; horizontal black line - equal proportion line $(50 \%-50 \%)$.
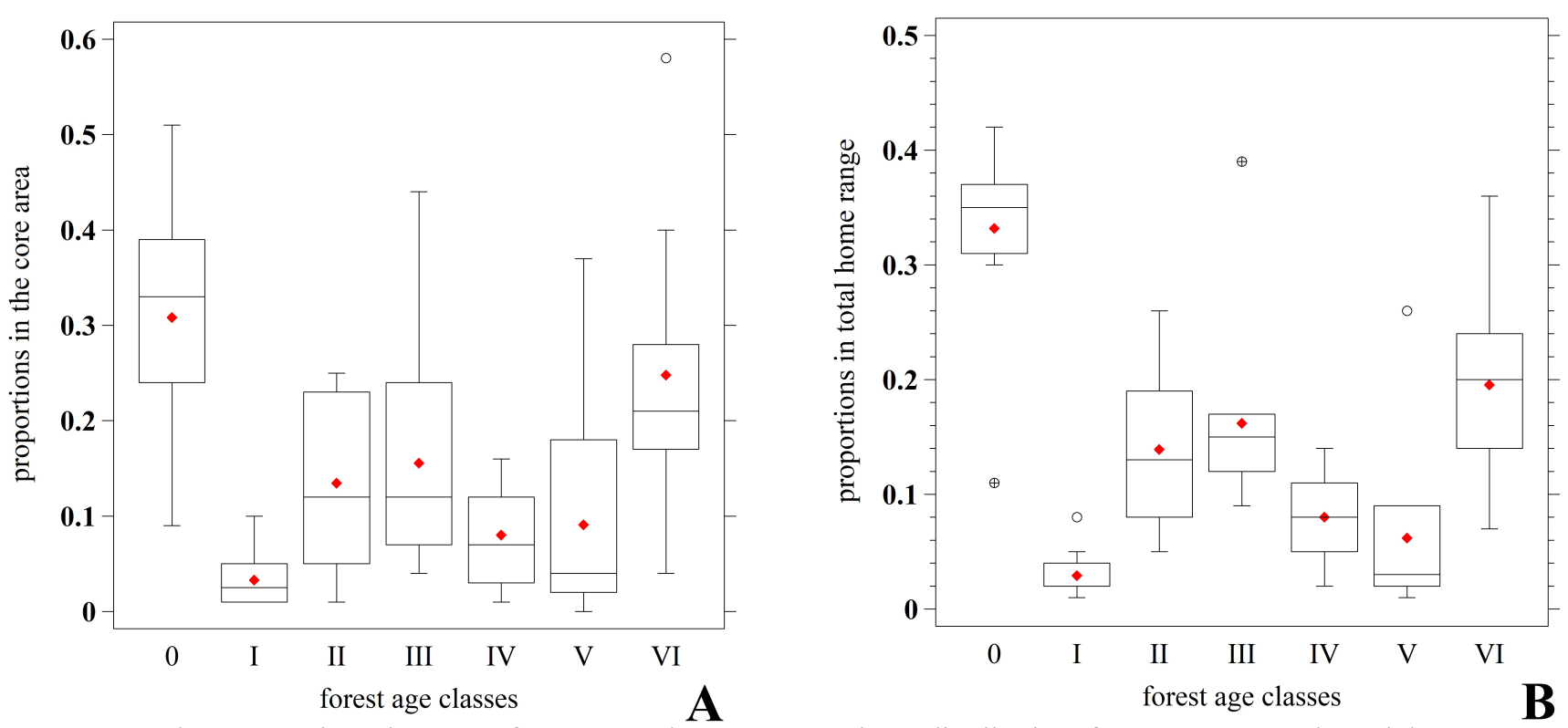

Fig. 3. Box-plot comparison between forest age classes' proportions distribution for core area and total home range. Designations: A - in core area; B - in total home range size; diamonds - average value, horizontal line - median value, box interquartile range, dots - outliers, dots with plus sign - extreme outliers. 
We compared the home range size during hyperphagia (between September and November) and outside this season with the density of feeding stations present (Table 3). No statistically significant difference was found between the home range sizes during and outside hyperphagia (Mann-Whitney test on medians, $\mathrm{W}=30.0, \mathrm{P}=0.871$ ) and between the density of feeding stations during hyperphagia and outside it (MannWhitney test on medians, $\mathrm{W}=27.0, \mathrm{P}=0.636$ ). Both average and median values for feeding stations density were higher during hyperphagia than outside of it (average 0.135 , median 0.140 per $1 \mathrm{~km}^{2}$ vs. average 0.104 , median 0.090 per $1 \mathrm{~km}^{2}$, respectively). No correlation was found between the home range size in hyperphagia and the density of feeding stations present in this range (Spearman correlation, $\mathrm{P}=0.102$ ), and between the home range size in hyperphagia and the masting area proportions (Spearman correlation, $\mathrm{P}=0.488$ ). A positive correlation was found outside the hyperphagia period between the home range size and the number of feeding stations (Pearson correlation $\rho=0.77, \mathrm{df}=7$,
$\mathrm{P}=0.026$ ). However, no correlation was found between the home range size and the density of feeding stations (Pearson correlation, $\mathrm{P}=0.389$ ).

\section{Home range and mobility}

All brown bears exhibited relatively similar 12-h displacement distances in the core area and total home range (Fig. 4A), despite the different density of feeding stations present (Fig. 4B). The average 12-h displacement distances varied between $292 \mathrm{~m}$ and 1410 $\mathrm{m}$ for the core area and between $297 \mathrm{~m}$ and $1519 \mathrm{~m}$ for the total area. The Mann-Whitney W-test on medians showed no statistically significant difference between the displacement distances in the core area and in total home range (Mann-Whitney test on medians, $\mathrm{W}=67.0, \mathrm{P}=0.696)$. No significant correlation was found between the average displacement distance and the density of feeding stations in the core area (Spearman correlation, $\mathrm{P}=0.995)$ and the average displacement distance and the density of feeding stations in the total home range (Spearman correlation, $\mathrm{P}=0.625$ ).

Table 3. Home range size and density of feeding stations during and outside hyperphagia*. The masting area coverage during the hyperphagia is presented as a percentage of the total (percentile 90) home range size

\begin{tabular}{|l|c|c|c|c|c|}
\hline \multirow{2}{*}{ BearID** } & \multicolumn{2}{|c|}{ Home range size, $\mathrm{km}^{2}$} & \multicolumn{2}{c|}{ Masting } & \multicolumn{2}{c|}{ Feeding stations density per $1 \mathrm{~km}^{2}$} \\
\cline { 2 - 6 } & Outside hyperphagia & Hyperphagia & Masting area in hyperphagia, $\%$ & Outside hyperphagia & Hyperphagia \\
\hline CB1 & 38.1 & 26.9 & $39.4 \%$ & 0.05 & 0.15 \\
\hline CB2 & 60.9 & 338.9 & $37.6 \%$ & 0.10 & 0.13 \\
\hline CB5 & 188.3 & 50.4 & $33.7 \%$ & 0.19 & 0.22 \\
\hline CB8 & 109.8 & 70.7 & $61.8 \%$ & 0.16 & 0.18 \\
\hline CB9 & 57.6 & 47.6 & $49.6 \%$ & 0.00 & 0.25 \\
\hline CB10 & 93.8 & 80.1 & $24.5 \%$ & 0.03 & 0.00 \\
\hline CB12 & 33.0 & 118.4 & $62.9 \%$ & 0.08 & 0.01 \\
\hline CB13 & 204.6 & 1089.6 & $28.5 \%$ & 0.08 \\
\hline
\end{tabular}

Note: * - As a hyperphagia, the period between September and November is considered; ** - here are included only those individuals, with data both during and outside hyperphagia, so without CB4.
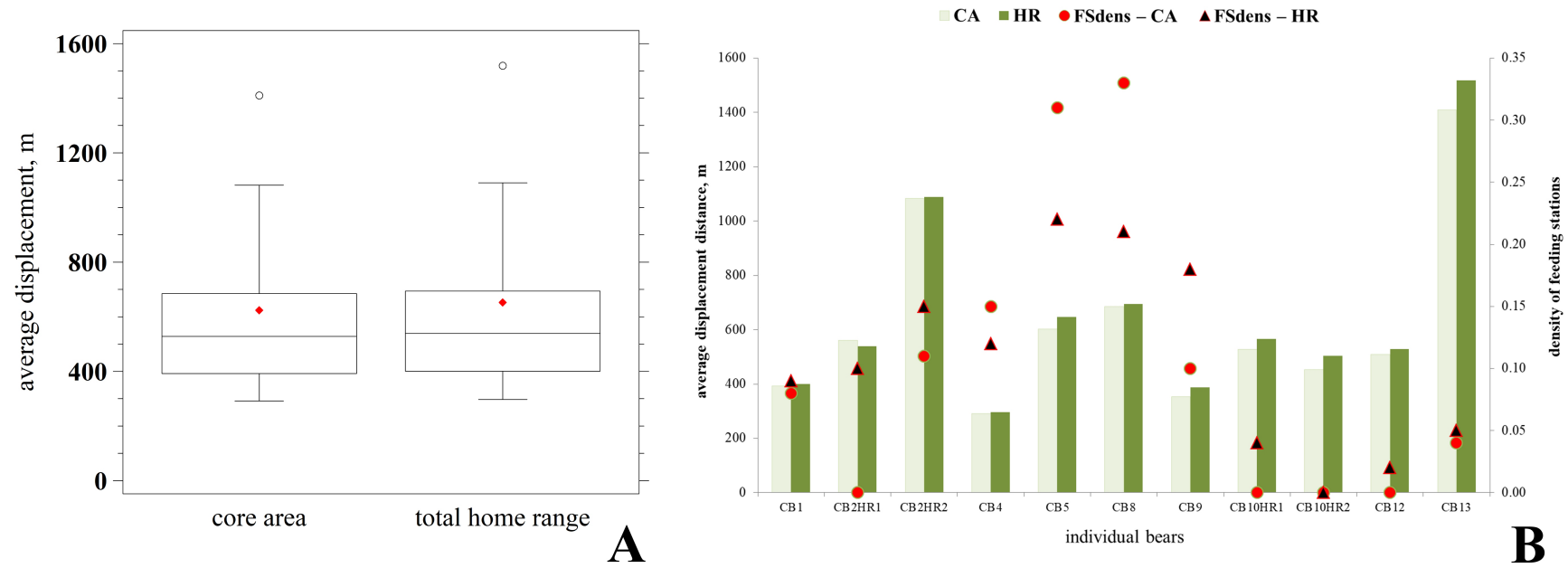

Fig. 4. Mobility of the GPS-collared individuals in the core area and total home range, expressed as average displacement distances and feeding station density. Designations: A - box-plot comparison between average displacement distance for all brown bears in the core and total home range area (diamonds - average value, horizontal line - median value, box - interquartile range, dots = outliers); $\mathrm{B}$ - comparison between the average displacement distance and the density of feeding stations in the core and total home range area per individual (CA - average displacement in the core area; HR - average displacement in the total home range; FSdens - CA (red dots) - density of feeding stations in the core area; FSdens - HR (black triangles) - density of feeding stations in total home range). 
The larger core areas were significantly and positively correlated with longer average displacement distances (Spearman's correlation, $\rho=0.86$, $\mathrm{df}=10, \mathrm{P}=0.006)$. The same was found for the total home ranges (Spearman's correlation, $\rho=0.85$, $\mathrm{df}=10, \mathrm{P}=0.008)$.

The average displacement distances were significantly and positively correlated with the masting areas size within the core area (Spearman's correlation, $\rho=0.65, \mathrm{df}=10, \mathrm{P}=0.04)$. The same was found for the displacement in the total home range (Spearman correlation, $\mathrm{P}=1$ ) vs. masting area size (Spearman's correlation, $\rho=0.76$, $\mathrm{df}=10, \mathrm{P}=0.016$ ). At the same time, the average displacement distances during and outside hyperphagia were similar (1455 $\mathrm{m}$ vs. $1475 \mathrm{~m}$ ) as more variability was expressed in-between the individuals during hyperphagia, than outside the hyperphagia (Fig. 5). Yet, the comparison of the medians did not show any statistically significant differences (Mann-Whitney test on medians, $\mathrm{W}=51.0, \mathrm{P}=0.377$ ). Two of the individuals (CB10 and CB13) were even more mobile during hyperphagia than outside this period.

CB13 expressed the highest mobility of all the brown bears (more than $1.2 \mathrm{~km}$ per $12 \mathrm{~h}$ ). Most of the brown bears kept their 12-h displacement distances below $600 \mathrm{~m}$. The two individuals with separate home ranges (CB2 and $\mathrm{CB} 10)$ had a different mobility in the first and second home ranges. $\mathrm{CB} 2$ showed almost two times longer average displacement distances in the second home range (after translocation), while $\mathrm{C} 10$ had even a little lower average displacement distance after settling in his second home range.

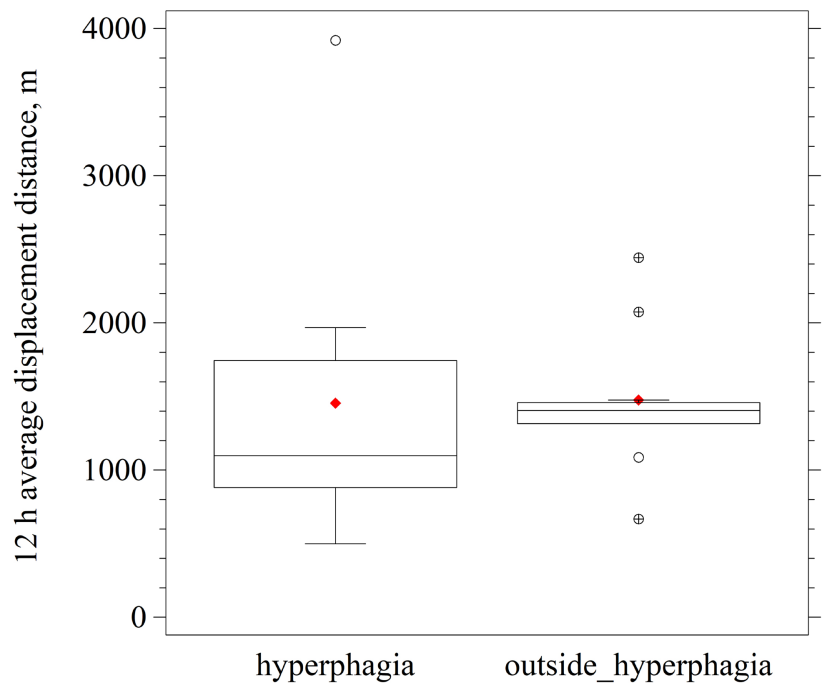

Fig. 5. Average displacement distance in hyperphagia and outside hyperphagia season. Designations: diamonds - average value, horizontal line - median value, box - interquartile range, dots - outliers, dots with plus sign - extreme outliers.

\section{Home range and hibernation}

The hibernation duration varied between 28 days (CB10) and four months (CB4, 122 days). A1most all individuals have chosen their winter den sites in the core areas of their home ranges (Table 4). Four out of the nine brown bears showed preferences for the percentile 0.1 , acting as a «nucleus» of the core area.

No significant correlation was found between the hibernation duration and masting area proportions (Pearson correlation, $\mathrm{P}=0.502$ ) and between the hibernation duration and density of feeding stations (Pearson correlation, $\mathrm{P}=0.375$ ) during hyperphagia. Yet, the brown bears which started their hibernation in November had slightly higher average masting area proportions (0.49) than those starting their hibernation in December (average masting area proportions: 0.39). The average density of feeding stations is slightly lower though $\left(0.15\right.$ per $\left.1 \mathrm{~km}^{2}\right)$ for the earlier hibernators, than for those starting hibernation in December $(0.16$ per 1 $\mathrm{km}^{2}$ ). Most of the earlier hibernators have either a higher proportion of masting area during hyperphagia (CB12) or a proportion masting areas above $0.30(30 \%)$ and a higher density of feeding stations (more than one feeding station per $10 \mathrm{~km}^{2}$ ). The only individual with a late and the shortest hibernation (CB10, 28 days) had the lowest masting area proportion (0.25) in his hyperphagia home range and no feeding stations.

\section{Discussion}

First, we should acknowledge that more feeding stations might be present in our study area. Before and during the hunting seasons, the hunters set temporary unannounced feeding stations that were impossible to locate and map. Secondly, we acknowledge that our small sample size and the outcome of this study are relative only to this local area and cannot be representative for the whole country. Yet, these are, according to our knowledge, the first efforts of trying to identify the complex relations between the home range size and mobility on one side and feeding stations presence, masting area proportions and hibernation on the other.

In this study, we worked under the assumption of Powell (2000) that the core area size is not a pre-requisite for the total area size. The core area size for our studied individuals ranged between $20 \%$ and $31 \%$ of the total home range. The total area showed a high variability. This variability was not only due to the sex differences, but also due to the sub-adults or cubs recently separated from 
their mothers $(\sim 2$ years old $)$. Such individuals (like CB1, CB2 and CB10) are more susceptible to segregation from larger and more dominant individuals. We also found that the males' home range size was more variable. Some literature sources stated that this might be due to segregation with an increased local population density (Nagy \& Haroldson, 1990), as this effect was more prominent in males than females due to matrilineal assemblages (Dahle et al., 2006). Further on, some publications provide proof that despite the variability and generally larger home ranges in the less-productive areas, the home range size was more related to social interactions than food availability (Nagy \& Haroldson, 1990; Dahle \& Swenson, 2003; Dahle et al., 2006). Thus, the comparison of the home range size between populations and even between regions would be meaningless, if these sizes were not considered together with the sex and age structure of the local population and its density. These data, regretfully, were seldom available, reported or compiled with the home range size to be able to draw robust conclusions.

Due to supplementary feeding, corn is part of the brown bear's diet (more specifically in autumn) in many countries throughout the species range. It is usually obtained by the brown bears either at hunter's ungulate feeding stations or in agricultural fields (Landers et al., 1979; Rigg \& Gorman, 2005). In Bulgaria, the usual approach is to provide corn as an appropriate supplement or substitute for the high energy acorns and nuts. Being concentrated and often abundant in resources, the artificial feeding stations were reported to increase the home range overlap, decrease home range size, increase group size, and reduce territoriality (Robb et al., 2008). This is also reported in other species, such as Cervus elaphus: the increase in density of feeding stations or the frequency of feeding, as well as the increase of species density, is directly leading to a decrease of the home range size (Jerina, 2012). A decrease of home range size with the increase of feeding stations density however, was not observed in our study (no correlation found both for core area and total home range). The lack of correlation between the average displacement distance and the density of feeding stations also supported the idea of low impact of the feeding stations presence on the home range formation. In some of the individuals an increase of the home range was observed possibly due to segregation by other more dominant conspecifics or/and the local management of the feeding stations (low and irregular food provided), complemented with the effect of a higher local density of the ungulates (competition). Usually the food is provided in too small quantities, not enough to sate a brown bear. Additionally, the ungulates often arrive earlier than the brown bears and consume most of the food provided, which force the brown bears to seek other sources (often, it means other feeding stations). Some brown bears were registered at several stations within duration of one night. Yet, this is not valid for all the studied individuals, as some never visited any feeding stations during the study period (provided, that visits were not omitted due to the time gaps between GPS fixes). This implies that the repeated observations of brown bears at feeding stations (recorded also with camera traps, see Electronic Supplement 1) were most probably due to habituated individuals to artificial feeding. Such habituation is often observed (Jerina et al., 2012; Steyaert et al., 2014), as brown bears are highly intelligent and adaptable and tend to utilise various food resources.

Table 4. Start date, end date, duration (in days) and location within the home range of the hibernation of the studied individuals

\begin{tabular}{|l|c|c|c|c|c|c|}
\hline Bear ID & $\begin{array}{c}\text { Start of } \\
\text { hibernation }\end{array}$ & $\begin{array}{c}\text { End of } \\
\text { hibernation }\end{array}$ & $\begin{array}{c}\text { Duration of } \\
\text { hibernation, days }\end{array}$ & $\begin{array}{c}\text { Percentile of the } \\
\text { home range kernel }\end{array}$ & $\begin{array}{c}\text { Masting area proportion } \\
\text { of home range during } \\
\text { hyperphagia }\end{array}$ & $\begin{array}{c}\text { Density of feeding } \\
\text { stations per 1 km during } \\
\text { hyperphagia }\end{array}$ \\
\hline CB12 & 23.11 .2017 & 05.03 .2018 & 102 & 0.3 & 0.63 & 0.01 \\
\hline CB2 & 26.11 .2009 & 20.03 .2010 & 114 & 0.8 & 0.38 & 0.13 \\
\hline CB5 & 26.11 .2016 & 20.03 .2017 & 114 & 0.6 & 0.34 & 0.28 \\
\hline CB8 & 28.11 .2016 & 15.02 .2017 & 79 & 0.1 & 0.62 & 0.18 \\
\hline CB9 & 03.12 .2016 & 03.03 .2017 & 90 & 0.3 & $-*$ & 0.25 \\
\hline CB4 & 11.12 .2014 & 12.04 .2015 & 122 & 0.4 & 0.39 & $-*$ \\
\hline CB1 & 20.12 .2007 & 25.01 .2008 & 36 & 0.1 & 0.29 & 0.15 \\
\hline CB13 & 20.12 .2017 & 20.01 .2018 & 31 & 0.1 & 0.25 & 0.08 \\
\hline CB10 & 10.02 .2018 & 10.03 .2018 & 28 & 0.1 & & 0.00 \\
\hline
\end{tabular}

Note: * - no data for this period. 
Brown bears that do not visit feeding stations might change their behaviour when the resources run low as a compensatory mechanism (Mattson et al., 1992; Oka et al., 2004; Schwartz et al., 2006). For example, a negative relationship between bait-station visitation and oak mast production was observed in a grizzly bear (Ursus arctos horribilis (Ord, 1815)) study, which set up a hypothesis that poor body condition «could increase bait station visitation by bears and vice versa» (Clark et al., 2005). So even if we did not observe such visits to the feeding stations during our study period, this did not mean that they will not start doing this during low resources. For example, CB9 never visited feeding stations, while he was with his mother. But a few months after dispersal (contact with the collar lost before that), this brown bear was found poached with a stomach full of corn, that in this area could be found only on a feeding station.

In the light of the finding that more than half of the studied individuals never visited feeding stations and no correlation was found between the density of feeding stations and the home range size, we looked at the other high energy source, acorns. The role of the mast was confirmed for the Ursus thibetanus which changed their habitat use in autumn (Kozakai et al., 2011). Other studies from North America and Japan had also supported the mast importance in autumn (Mattson et al., 1992; Schwartz et al., 2006) as bears rely on the mast during hyperphagia to increase their body mass in preparation for hibernation (Hertel et al., 2019). We hypothesised that the distribution of the masting areas and their proportions were important for a better understanding of the role of the feeding stations and the formation of the home range itself. Although the mast production is a seasonal event, we worked under the assumption that brown bears, like other animals, would memorise and integrate such sources of high nutritional value in their "cognitive map» (Powell, 2000) to maximise the chances for survival.

Forest management is suspected to affect both brown bear habitats and their behaviour through the created age class heterogeneity. Young forests (age class I) found in early succession areas, after a calamity, disturbance or timber harvesting, have a canopy in the process of closure, thus being an abundant source for berries, i.e. an essential part of the brown bear's diet. During the process of re-establishment of mature overstory (classes II and III), the tree density increases, making them suitable for day resting places. Mature forest (classes IV and V) provides the highest nutritional food, making them vital during the season of hyperphagia, while old forest (age class VI) provides opportunities for denning sites and low disturbance. All of the above requires additional analyses in the search of the unrevealed factors affecting the home range size and distribution (Goodrum et al., 1971; Stransky \& Roese, 1984; Mitchell \& Powell, 2003). Despite the variability of the masting areas proportions and age class heterogeneity, the lack of significant difference in these two factors between the core area and the total home range implied that these resources were not concentrated in the core area of the species, but were rather uniformly distributed throughout the whole area. This is a logical outcome, as the areas with mast potential are used only seasonally.

The brown bear mobility in hyperphagia can be explained by mast, as well as berry production. Despite the high value of the masting area size, it explained a very low percent of the displacement distance variability in our GPS-collared brown bears. During our study, the Fagus mast production was high and it was expected that it would result in shorter displacement. Instead, the mobility of the brown bears was not directly connected to the size of the masting areas. Even more, the lack of difference between the average displacement during and outside the hyperphagia season suggested that the brown bears were probably foraging on other food sources, such as artificial food.

Additionally, we observed a positive significant correlation between the home range size (core area and total home range) with the masting areas size, although the average displacement distances during and outside hyperphagia were similar. This was contradicting to other studies where during berry seasons a shift towards shorter displacement was noted in brown bears (Ordiz et al., 2012) or a negative relationship between movement distances and mast production was found in Ursus thibetanus (Koike et al., 2012). The specificity of the mast is the variability of its production and a synchronicity over large spatial areas (Silvertown, 1980), which is supposed to affect the overall bear movement. When low mast during hyperphagia occurs, Kozakai et al. (2011) found that $U$. thibetanus increased their movement activity (Koike et al., 2012), increased their home range size, and even made short-range excursions outside their home range in the search of food (Pelchat \& Ruff, 1986; Koike et al., 2012). The latter was observed for individual CB13 in our study, who during the hyperphagia period spent several days in nearby areas, before returning to his established area.

The lack of correlation between home range size in hyperphagia with the density of feeding stations and with the masting area proportions and between average displacement distance and the density of feeding stations implied than none of these two factors (density of feeding stations and the masting area) were solely 
responsible for the formation of the home range in hyperphagia. Additionally, the similarity in the size of the home range during and outside the hyperphagia season suggested a balance between the variables forming it during these periods. This is a reason to reject the first hypothesis. The lack of statistical support for the difference of the role of the artificial feeding stations during hyperphagia and outside the hyperphagia allows us to confirm the second hypothesis.

The patterns in hibernation are still not entirely understood (Manchi \& Swenson, 2005; Krofel et al., 2017). Most of the brown bears in our study hibernate in their core area, predominantly in its centre $(0.1$ percentile). As far as we know, there is no such study with which we can compare these findings.

After seven years of monitoring, Gunchev (1989) reported that brown bears in this region normally enter into hibernation in December. The level of artificial feeding and the masting potential in Gunchev's (1989) study were similar as today, due to the fact that the management has not changed. Hence, the data about the hibernation start might be considered valid today. Our results though point at an earlier hibernation, starting in November. No correlation was found between hibernation duration and masting area proportions/ density of feeding stations. But these results should be treated cautiously with the proviso that our sample is not big enough for robust conclusions. The insignificant, but yet present, difference during hyperphagia in average masting area proportions and the density of feeding stations between the «earlier (November)» and «normal (December)» imply that earlier hibernators probably rely more on mast production, while the normal hibernators might stay longer where more feeding stations are present. This is in compliance with Pigeon et al. (2016) who suggested that access to food supply can affect denning chronology and continuousness in terms of higher food availability resulting in later den entering. Research in North America and Southern Europe has even shown that weather conditions and food availability can result in bears remaining active during winter (Van Daele et al., 1990; Huber \& Roth, 1997; Linnell et al., 2000). So, the outcomes from this part of our study give us the reason that currently we could reject the third hypothesis.

\section{Conclusions}

In conclusion, summarising the outcome and with the acknowledgement of the small sample size, we can state that the first and the third hypothesis were rejected, while the second hypothesis was confirmed. The reason for this is mainly because we did not found a solid proof that there was a dominant variable responsible for formation of the annual brown bear's home range and those during and outside hyperphagia in our study area. Further studies on forest age heterogeneity and mast production are needed with a larger sample size.

\section{Acknowledgements}

We would like to thank the Central Balkan National Park Directorate (Nikolay Staikov and Anton Stanchev) and «Rusalka» State Hunting Enterprise (Vasil Shkembov) for the logistic support and assistance in collecting the necessary information. We also thank Alexander Dutsov and Kostadin Valchev (Balkani Wildlife Society) for their contribution and involvement in the fieldwork. This work was partially supported by two sources: 1) the Bulgarian Ministry of Education and Science under the National Research Program «Young scientists and postdoctoral students» approved by DCM \# 577 / 17.08.2018 and 2) State Enterprise for Management of Environmental Protection Activities (PUDOOS).

\section{Supporting Information}

Detailed characteristics of feeding stations (Electronic Supplement 1: Feeding stations details - GPS co-ordinates, forestry/national park unit, locality and frequency of feeding which is most commonly applied), and photos of brown bears on feeding stations (Electronic Supplement 2: Camera-trap photos of brown bears on feeding stations in the study area) may be found in the Supporting Information here.

\section{References}

Bojarska K., Drobniak S., Jakubiec Z., Zyśk-Gorczyńska E. 2019. Winter insomnia: How weather conditions and supplementary feeding affect the brown bear activity in a long-term study. Global Ecology and Conservation 17: e00523. DOI: 10.1016/j.gecco.2019.e00523

Chapron G., Kaczensky P., Linnell J.D.C., von Arx M., Huber D., Andrén H., López-Bao J.V., Adamec M., Álvares F., Anders O., Balčiauskas L., Balys V., Bedő P., Bego F., Blanco J.C., Breitenmoser U., Brøseth H., Bufka L., Bunikyte R., Ciucci P., Dutsov A., Engleder T., Fuxjäger C., Groff C., Holmala K., Hoxha B., Iliopoulos Y., Ionescu O., Jeremić J., Jerina K. et al. 2014. Recovery of large carnivores in Europe's modern human-dominated landscapes. Science 346(6216): 1517-1519. DOI: 10.1126/science. 1257553

Ćirović D., de Gabriel Hernando M., Paunović M., Karamanlidis A.A. 2015. Home range, movements, and activity patterns of a brown bear in Serbia. Ursus 26(2): 79-85. DOI: 10.2192/ursus-d-15-00010

Clark J.D., van Manen F.T., Pelton M.R. 2005. Bait Stations, Hard Mast, and Black Bear Population Growth in Great Smoky Mountains National Park. Journal of Wildlife Management 69(4): 1633-1640. DOI: 10.2193/0022-541X(2005)69[1633:BSHMAB]2.0.CO;2

Dahle B., Swenson J.E. 2003. Home ranges in adult Scandinavian brown bears (Ursus arctos): Effect of mass, 
sex, reproductive category, population density and habitat type. Journal of Zoology 260(4): 329-335. DOI: $10.1017 / \mathrm{s} 0952836903003753$

Dahle B., Støen O.G., Swenson J.E. 2006. Factors influencing home-range size in subadult brown bears. Journal of Mammalogy 87(5): 859-865. DOI: 10.1644/05-MAMM-A-352R1.1

De Solla S.R., Bonduriansky R., Brooks R.J. 1999. Eliminating autocorrelation reduces biological relevance of home range estimates. Journal of Animal Ecology 68(2): 221-234. DOI: 10.1046/j.13652656.1999.00279.x

Delkov N. 1984. Dendrology [Dendrologiya]. (in Bulgarian). Sofia, Bulgaria: Zemizdat Press. 331 p.

Fležar U., Costa B., Bordjan D., Jerina K., Krofel M. 2019. Free food for everyone: artificial feeding of brown bears provides food for many non-target species. European Journal of Wildlife Research 65(1): 1. DOI: $10.1007 / \mathrm{s} 10344-018-1237-3$

Gavrilov G., Zlatanova D., Spasova V., Valchev K., Dutsov A. 2015. Home range and habitat use of brown bear in Bulgaria: The first data based on GPS-Telemetry. Acta Zoologica Bulgarica 67(4): 493-499.

Goodrum P.D., Reid V.H., Boyd C.E. 1971. Acorn yields, characteristics, and management criteria of oak for wildlife. Journal of Wildlife Management 35: 520-532.

Gunchev R.R. 1989. Research on the numbers, the biology and the ecology of the brown bear (Ursus arctos L.) in Stara Planina mountain. PhD Thesis. Sofia: High Forestry - Technical Institute. 128 p. [In Bulgarian]

Hertel A.G., Zedrosser A., Kindberg J., Langvall O., Swenson J.E. 2019. Fluctuating mast production does not drive Scandinavian brown bear behavior. Journal of Wildlife Management 83(3): 657-668. DOI: 10.1002/jwmg.21619

Huber D., Roth H.U. 1997. Denning of brown bears in Croatia. Bears: Their Biology and Management 9: 79-83. DOI: $10.2307 / 3872664$

Hundeshagen J.C. 1826. Die Forstabschätzung auf neuen, wissenschaftlichen Grundlagen : nebst einer Charakteristik und Vergleichung aller bisher bestandenen Forsttaxations-Methoden. Tübingen: Laupp. 483 p.

Jerina K. 2012. Roads and supplemental feeding affect home-range size of Slovenian red deer more than natural factors. Journal of Mammalogy 93(4): 11391148. DOI: 10.1644/11-mamm-a-136.1

Jerina K., Krofel M., Stergar M., Videmšek U. 2012. Factors Affecting Brown Bear Habituation To Humans: a GPS Telemetry Study. Technical report. Ljubljana: University of Ljubljana. $18 \mathrm{p}$.

Jonkel J.J. 1993. A manual for handling bears for managers and researchers. Montana: U.S. Fish and Wildlife Service. $142 \mathrm{p}$.

Kaczensky P., Chapron G., von Arx M., Huber D., Andrén H., Linnell J (Eds). 2013. Status, management and distribution of large carnivores - bear, lynx , wolf \& wolverine - in Europe. Part 2 (Country reports). European Commission Series. Available from https://ec.europa.eu/environment /nature/con- servation/species/carnivores/pdf/task_1_part2_species_country_reports.pdf.

Kavčič I., Adamič M., Kaczensky P., Krofel M., Jerina K. 2013. Supplemental feeding with carrion is not reducing brown bear depredations on sheep in Slovenia. Ursus 24(2): 111-119. DOI: 10.2192/URSUS-D-12-00031R1.1

Kavčič I., Adamič M., Kaczensky P., Krofel M., Kobal M., Jerina K. 2015. Fast food bears: brown bear diet in a human-dominated landscape with intensive supplemental feeding. Wildlife Biology 21(1): 1-8. DOI: 10.2981/wlb.00013

Koike S., Kozakai C., Nemoto Y., Masaki T., Yamazaki K., Abe S., Nakajima A., Umemura Y., Kaji K. 2012. Effect of Hard Mast Production on Foraging and Sex-Specific Behavior of the Asiatic Black Bear ( $U r$ sus thibetanus). Mammal Study 37(1): 21-28. DOI: 10.3106/041.037.0103

Kojola I., Heikkinen S. 2012. Problem brown bears Ursus arctos in Finland in relation to bear feeding for tourism purposes and the density of bears and humans. Wildlife Biology 18(3): 258-263. DOI: 10.2981/11-052

Kozakai C., Yamazaki K., Nemoto Y., Nakajima A., Koike S., Abe S., Masaki T., Kaji K. 2011. Effect of mast production on home range use of Japanese black bears. Journal of Wildlife Management 75(4): 867875. DOI: $10.1002 /$ jwmg. 122

Kozakai C., Yamazaki K., Nemoto Y., Nakajima A., Umemura Y., Koike S., Goto Y., Kasai S., Abe S., Masaki T., Kaji K. 2013. Fluctuation of daily activity time budgets of Japanese black bears: relationship to sex, reproductive status, and hard-mast availability. Journal of Mammalogy 94(2): 351-360. DOI: 10.1644/11-mamm-a-246.1

Krofel M., Špacapan M., Jerina K. 2017. Winter sleep with room service: denning behaviour of brown bears with access to anthropogenic food. Journal of Zoology 302(1): 8-14. DOI: 10.1111/jzo.12421

Landers J.L., Hamilton R.J., Johnson A.S., Marchinton R.L. 1979. Foods and Habitat of Black Bears in Southeastern North Carolina. Journal of Wildlife Management 43(1): 143-153. DOI: 10.2307/3800645

LCIE. 2018. Policy Support Statements of the Large Carnivore Initiative for Europe (LCIE) - The use of artificial feeding as a management tool for large carnivore populations and their prey, with a particular emphasis on the brown bear. Large Carnivore Initiative for Europe. 2 p.

Linnell J.D.C., Swenson J.E., Andersen R., Barnes B. 2000. How vulnerable are denning bears to disturbance? Wildlife Society Bulletin 28(2): 400-413. DOI: $10.2307 / 3783698$

Linnell J.D.C., Salvatori V., Boitani L. 2008. Guidelines for population level management plans for large carnivores in Europe. A Large Carnivore Initiative for Europe report prepared for the European Commission (contract 070501/2005/424162/MAR/B2). 83 p.

Linnell J.D.C., Cretois B., Nilsen E.B., Rolandsen C.M., Solberg E.J., Veiberg V., Kaczensky P., Van Moorter B., Panzacchi M., Rauset G.R., Kaltenborn B. 2020. 
The challenges and opportunities of coexisting with wild ungulates in the human-dominated landscapes of Europe's Anthropocene. Biological Conservation 244: 108500. DOI: 10.1016/j.biocon.2020.108500

Mattson D.J., Blanchard B.M., Knight R.R. 1992. Yellowstone Grizzly Bear Mortality, Human Habituation, and Whitebark Pine Seed Crops. Journal of Wildlife Management 56(3): 432-442. DOI: 10.2307/3808855

MAFF. 2001. Ministry of Agriculture, Food and Forestry. Regulation of Hunting and Game Conservation Act. Chapter four: Game management and conservation; Section I: Game management. Art. 51. Available from https://www.lex.bg/laws/ldoc/-12290559

Manchi S., Swenson J.E. 2005. Denning behaviour of Scandinavian brown bears Ursus arctos. Wildlife Biology 11(2): 123-132. DOI: 10.2981/0909-6396(2005)11[123:dbosbb]2.0.co;2

McLoughlin P.D., Ferguson S.H., Messier F. 2000. Intraspecific variation in home range overlap with habitat quality: a comparison among brown bear population. Evolutionary Ecology 14(1): 39-60. DOI: 10.1023/A:1011019031766

Mitchell M.S., Powell R.A. 2003. Response of Black Bears to Forest Management in the Southern Appalachian Mountains. Journal of Wildlife Management 67(4): 692-705. DOI: 10.2307/3802676

MOEW. 2008. Action plan for the Brown bear in Bulgaria [English version]. Sofia, Bulgaria: Ministry of Environment and Waters series. $144 \mathrm{p}$.

Nagy J.A.S., Haroldson M.A. 1990. Comparisons of Some Home Range and Population Parameters among Four Grizzly Bear Populations in Canada. Ursus 8: 227-235.

Oka T., Miura S., Masaki T., Suzuki W., Osumi K., Saitoh S. 2004. Relationship Between Changes in Beechnut Production and Asiatic Black Bears in Northern Japan. Journal of Wildlife Management 68(4): 979-986. DOI: 10.2193/0022-541x(2004)068[0979:rbcibp]2.0.co;2

Ordiz A., Støen O.G., Sæbø S., Kindberg J., Delibes M., Swenson J.E. 2012. Do bears know they are being hunted? Biological Conservation 152: 21-28. DOI: 10.1016/j.biocon.2012.04.006

Pelchat B.O., Ruff R.L. 1986. Habitat and Spatial Relationships of Black Bears in Boreal Mixedwood Forest of Alberta. Ursus 6: 81-92.

Pigeon K.E., Cardinal E., Stenhouse G.B., Côté S.D. 2016. Staying cool in a changing landscape: the influence of maximum daily ambient temperature on grizzly bear habitat selection. Oecologia 181(4): 1101-1116. DOI: $10.1007 / \mathrm{s} 00442-016-3630-5$

Pop I.M., Bereczky L., Chiriac S., Iosif R., Nita A., Popescu V.D., Rozylowicz L. 2018. Movement ecology of brown bears (Ursus arctos) in the Romanian Eastern Carpathians. Nature Conservation 26: 15-31. DOI: 10.3897/natureconservation.26.22955

Powell R.A. 2000. Animal home ranges and territories and home range estimators. In: L. Boitani, T.K. Fuller (Eds.): Research technologies in animal ecologycontroversies and consequences. New York, NY: Columbia University Press. P. 65-110.
Rigg R., Gorman M. 2005. Diet of brown bears (Ursus arctos): new results from the Tatras region and a comparison of research methods. In: Výskum a ochrana cicavcov na Slovensku. Vol. 7. P. 61-79.

Robb G.N., McDonald R.A., Chamberlain D.E., Bearhop S. 2008. Food for thought: Supplementary feeding as a driver of ecological change in avian populations. Frontiers in Ecology and the Environment 6(9): 476484. DOI: 10.1890/060152

Samuel M.D., Pierce D.J., Garton E.O. 1985. Identifying Areas of Concentrated Use within the Home Range. Journal of Animal Ecology 54(3): 711-719. DOI: 10.2307/4373

Schwartz C.C., Haroldson M.A., White G.C., Harris R.B., Cherry S., Keating K.A., Moody D., Servheen C. 2006. Temporal, Spatial, and Environmental Influences on the Demographics of Grizzly Bears in the Greater Yellowstone Ecosystem. Wildlife Monographs 161: 1-68. DOI: 10.2193/0084-0173(2006)161[1:tsaeio]2.0.co;2

Seaman D.E., Powell R.A. 1990. Identifying Patterns and Intensity of Home Range Use. Ursus 8: 243-249.

Selva N., Berezowska-Cnota T., Elguero-Claramunt I. 2014. Unforeseen effects of supplementary feeding: Ungulate baiting sites as hotspots for ground-nest predation. PLoS ONE 9(3): e90740. DOI: 10.1371/journal.pone.0090740

Selva N., Teitelbaum C.S., Sergiel A., Zwijacz-Kozica T., Zięba F., Bojarska K., Mueller T. 2017. Supplementary ungulate feeding affects movement behavior of brown bears. Basic and Applied Ecology 24: 68-76. DOI: 10.1016/j.baae.2017.09.007

Seryodkin I.V., Paczkowski J., Borisov M.Y., Petrunenko Y.K. 2017. Home ranges of brown bears on the Kamchatka peninsula and Sakhalin Island. Contemporary Problems of Ecology 10(6): 599-611. DOI: 10.1134/ S1995425517060129

Silvertown J.W. 1980. The evolutionary ecology of mast seeding in trees. Biological Journal of the Linnean Society 14(2): 235-250. DOI: 10.1111/j.10958312.1980.tb00107.x

Steyaert S.M.J.G., Kindberg J., Jerina K., Krofel M., Stergar M., Swenson J.E., Zedrosser A. 2014. Behavioral correlates of supplementary feeding of wildlife: Can general conclusions be drawn? Basic and Applied Ecology 15(8): 669-676. DOI: 10.1016/j.baae.2014.10.002

Steyaert S.M., Zedrosser A., Elfström M., Ordiz A., Leclerc M., Frank S.C., Kindberg J., Støen O.G., Brunberg S., Swenson J.E. 2016. Ecological implications from spatial patterns in human-caused brown bear mortality. Wildlife Biology 22(4): 144-152. DOI: 10.2981/wlb.00165

Štofik J., Merganič J., Merganičová K., Saniga M. 2013. Seasonal changes in food composition of the brown bear (Ursus arctos) from the edge of its occurrence - Eastern Carpathians (Slovakia). Folia Zoologica 62(3): 222-231. DOI: 10.25225/fozo.v62.i3.a8.2013

Stransky J.J., Roese J.H. 1984. Promoting soft mast for wildlife in intensively managed forests. Wildlife Society Bulletin 12(3): 234-239.

van Beeck Calkoen S.T.S., Mühlbauer L., Andrén H., Apollonio M., Balčiauskas L., Belotti E., Carranza J., Cottam 
J., Filli F., Gatiso T.T., Hetherington D., Karamanlidis A.A., Krofel M., Kuehl H.S., Linnell J.D.C., Müller J., Ozolins J., Premier J., Ranc N., Schmidt K., Zlatanova D., Bachmann M., Fonseca C., Ionescu O., Nyman M., Sprem N., Sunde P., Tannik M., Heurich M. 2020. Ungulate management in European national parks: Why a more integrated European policy is needed. Journal of Environmental Management 260: 110068. DOI: 10.1016/j.jenvman.2020.110068
Van Daele L.J., Barnes Jr V.G., Smith R.B. 1990. Denning characteristics of brown bears on Kodiak Island, Alaska. Bears: Their Biology and Management 8: 257-267.

Wall J. 2014. Movement Ecology Tools for ArcGIS (ArcMET). Version 10.3.1 v1.

Worton B.J. 1989. Kernel Methods for Estimating the Utilization Distribution in Home-Range Studies. Ecology 70(1): 164-168. DOI: 10.2307/1938423

\title{
ИНДИВИДУАЛЬНЫЙ УЧАСТОК, МОБИЛЬНОСТЬ, ЗИМНИЙ СОН БУРЫХ МЕДВЕДЕЙ (URSUS ARCTOS, URSIDAE) НА ТЕРРИТОРИЯХ С ПОДКОРМОЧНЫМИ ПЛОЩАДКАМИ
}

\author{
В. Р. Тодоров ${ }^{1,2}$, Д. П. Златанова ${ }^{3}$, К. В. Вальчинкова ${ }^{1}$ \\ ${ }^{1}$ Институт исследований биоразнообразия и экосистем Болгарской академии наук, Болгария \\ e-mail:vladimirtodorov.r@gmail.com,kvalchinkova@gmail.com \\ ${ }^{2}$ Балканское общество дикой природы, Болгария \\ ${ }^{3}$ Софийский университет имени святого Климента Охридского, Болгария \\ e-mail: dianazlatanova@biofac.uni-sofia.bg
}

\begin{abstract}
Дополнительная подкормка, которая, хотя и является обычной практикой, редко изучается с точки зрения ее воздействия на нецелевые виды, такие как бурый медведь (Ursus arctos). Нами проведены GPS-GSMтелеметрические исследования девяти особей бурого медведя (из примерно 100 особей, предположительно, населяющих территорию исследования) с целью выяснить, как подкормочные площадки влияют на размер индивидуального участка, мобильность и зимний сон. Мы выдвинули три гипотезы: 1) наблюдается корреляция между размером индивидуального участка и плотностью размещения подкормочных площадок; 2) влияние подкормочных площадок не меняется во время и вне нажировочного периода; 3) плотность подкормочных площадок влияет на зимний сон, независимо от участков с плодоносящими деревьями, присутствующих на индивидуальном участке, и неоднородности возраста леса. Проведенный анализ показал, что общая площадь индивидуального участка в среднем составила 148.9 км$^{2}(\min -\max$ :

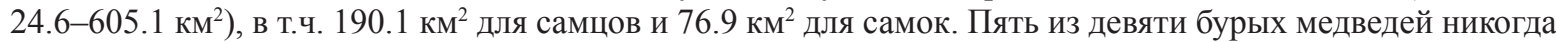
не посещали подкормочных площадок, и плотность размещения таких площадок не объясняла вариабельность размеров индивидуального участка. Поэтому мы не получили доказательств, подтверждающих нашу первую гипотезу. Не было найдено никаких доказательств, отклоняющих вторую гипотезу. В то же время третья гипотеза на данный момент была отклонена с оговоркой, что наша выборка недостаточно велика для надежных выводов. В отличие от результатов других опубликованных исследований, нами не выявлено статистически значимых различий при сравнении размера индивидуального участка и среднего расстояния смещения во время и вне нажировочного периода. Несмотря на вариабельность доли площадей нажировочных участков и неоднородность деревьев по возрастным классам, мы не обнаружили существенной разницы между «ядром» и общей площадью индивидуального участка для этих двух факторов. Это означало, что эти ресурсы не были сконцентрированы в «ядре» индивидуального участка бурого медведя, а были довольно равномерно распределены по всей его территории. Мы обнаружили, что ни плотность станций дополнительного питания, ни доля площадей нажировочного участка не являются единственной причиной формирования индивидуального участка во время нажировочного периода. Кроме того, сходство размеров индивидуальных участков во время и вне нажировочного периода предполагало баланс между переменными, формирующими индивидуальный участок в эти периоды. В нашем исследовании большинство особей бурых медведей в «ядре» индивидуального участка переходят в состояние зимнего сна, преимущественно в самом его центре (0.1 процентиль), поскольку переход особей в зимний сон отмечался в более раннее время, чем сообщалось для этого региона по данным других исследований. Необходимы дальнейшие исследования с большим размером выборки о роли неоднородности возраста леса и объема нажировочного корма на формирование индивидуального участка.
\end{abstract}

Ключевые слова: GPS-телеметрия, нажировочный корм, нажировочный период, неоднородность возраста леса, подкормочная площадка 